\title{
PENGARUH KARAKTERISTIK PERJALANAN, KARAKTERISTIK INDIVIDU, DAN KARAKTERISTIK TEMPAT TINGGAL TERHADAP KEPUTUSAN PILIHAN LOKASI RUMAH DI JABODETABEK
}

\author{
Patrick Louis $^{1}$ dan Leksmono Suryo Putranto ${ }^{2}$
}

\author{
${ }^{1}$ Program Studi Sarjana Teknik Sipil, Universitas Tarumanagara, Jl. Letjen S. Parman No.1 Jakarta \\ Email: patrick.louis898@gmail.com \\ ${ }^{2}$ Program Studi Sarjana Teknik Sipil, Universitas Tarumanagara, Jl. Letjen S. Parman No.1 Jakarta \\ Email: lexy_putranto@yahoo.co.id
}

\begin{abstract}
ABSTRAK
Penggunaan transportasi darat menjadi pilihan utama masyarakat Indonesia untuk melakukan perjalanan. Ketersediaan transportasi akan memperlancar kegiatan manusia. Sehingga dalam menjalankan aktivitasnya diharapkan waktunya tidak habis dalam perjalanan. Pada umumnya, masyarakat akan mencari lingkungan tempat tinggal yang mudah diakses sehingga kegiatannya tidak terganggu. Jabodetabek merupakan salah satu wilayah yang warganya melakukan perjalanan terbanyak setiap harinya. Sehingga faktor karakteristik perjalanan, karakteristik individu, dan karakteristik tempat tinggal menjadi penting terhadap perilaku pemilihan lokasi rumah. Kuesioner dibagikan kepada 102 responden. Yang terdiri dari 50 responden yang mengisi kuesioner langsung dan 52 responden yang mengisi kuesioner daring. Kuesioner terbagi 2 bagian. Bagian pertama berisi tentang data umum responden. Bagian kedua berisi karakteristik-karakteritik yang mempengaruhi keputusan pemilihan lokasi rumah. Data dianalisis menggunakan metode One Sample T-test dan korelasi Pearson terhadap data umum responden untuk mengetahui besaran pengaruh faktor-faktor yang mempengaruhi keputusan pemilihan lokasi rumah. Berdasarkan hasil penelitian, faktor keamanan lingkungan memiliki pengaruh paling besar dalam keputusan pilihan lokasi rumah.
\end{abstract}

Kata kunci: pilihan lokasi rumah, karakteristik perjalanan, karakteristik individu, karakteristik tempat tinggal, JABODETABEK.

\section{PENDAHULUAN}

\section{Latar Belakang}

Di Indonesia penggunaan moda transportasi darat telah menjadi pilihan utama masyarakat untuk melakukan perjalanan. Ketersediaan transportasi akan memperlancar kegiatan manusia, terutama manusia sangat mementingkan waktu yang ada, sehingga dalam menjalankan aktivitasnya diharapkan waktunya tidak habis dalam perjalanan. Pada umumnya, masyarakat akan mencari lingkungan yang mudah diakses baik dengan transit maupun berjalan (Levine, 1998).

Rumah tinggal merupakan kebutuhan pokok yang ketiga setelah pangan dan sandang. Selain berfungsi untuk melindungi diri dari alam juga berfungsi untuk meningkatkan harkat hidup sebagaimana bangunan pada umumnya. Rumah tinggal juga dituntut untuk memenuhi kebutuhan-kebutuhan yang sesuai dengan zamannya, antara lain sebagai tempat berkumpul anggota keluarga, tempat untuk melakukan bermacam-macam kegiatan meliputi kegiatan ekonomi, produksi, pengasuhan dan pendidikan anak, merawat orang tua, kegiatan sosial, dan sebagainya.

Namun untuk beberapa negara yang tingkat kepadatan penduduknya tinggi dan persebarannya tidak merata seperti Indonesia, masalah tempat tinggal masih menjadi polemik. Masih banyak penduduk Indonesia, baik di desa maupun di kota, yang hidup di tempat yang kurang sehat bahkan bisa dikatakan kurang layak untuk ditinggali. Permasalahan tempat tinggal yang dihadapi oleh penduduk yang tinggal di daerah pedesaan pada umumnya adalah lemahnya kemampuan ekonomi serta kurangnya pendidikan dan pengetahuan tentang bagaimana membangun rumah yang sehat dan layak. Sedangkan permasalahan yang dihadapi oleh penduduk di perkotaan adalah kurangnya lahan perumahan di kota yang mengakibatkan harga rumah atau tanah sangat tinggi dan sulit didapatkan, ditambah lagi dengan permasalahan seperti lemahnya tingkat ekonomi penduduk kota yang berpengaruh pada kemampuan untuk memiliki rumah. Van Lindert dan Westen (1991) menemukan bahwa banyak rumah tangga miskin lebih memilih untuk tetap tinggal di akomodasi sewa yang berlokasi di pusat ketimbang menjadi pemilik di pinggir kota.

Saat ini pun dalam membeli rumah masyarakat tidak hanya melihat faktor harga saja namun mereka mulai mempertimbangkan faktor-faktor lain seperti faktor lokasi, faktor bangunan, dan faktor lingkungan. Alasan 
masyarakat mempertimbangkan faktor harga karena hal tersebut berkaitan dengan pendapatan mereka. Bagi mereka yang memiliki pendapatan besar mungkin harga tidak akan menjadi masalah, tapi mereka lebih mempertimbangkan faktor lokasi dan kualitas produk dalam hal ini faktor bangunan. Di kalangan masyarakat dengan pendapatan rendah, khususnya yang bergantung pada sumber pendapatan informal/tidak tetap, lokasi rumah tidak hanya dipilih berdasarkan faktor sosial ekonomi seperti aksesibilitas ke pusat kota tapi juga berdasarkan jejaring hubungan sosial dan keluarga (Bonvalet an Dureau, 2000). Selain sumber pendapatan, rasa komunitas yang kuat menjadi alasan kalangan masyarakat untuk tetap tinggal di satu daerah tertentu (Abraham dan Rodriguez, 2011).

\section{Batasan Masalah}

Adapun batasan-batasan di dalam penulisan penelitian ini, antara lain:

1. Wilayah yang digunakan dalam penelitian ini adalah JABODETABEK (Jakarta, Bogor, Depok, Tangerang, dan Bekasi).

2. Subjek penelitian merupakan individu yang memiliki kewenangan dalam pengambilan keputusan pemilihan lokasi rumah yang memiliki rumah dalam 5 (lima) tahun terakhir.

\section{Rumusan Masalah}

Rumusan masalah yang dibahas:

1. Bagaimana karakteristik tempat tinggal mempengaruhi pilihan lokasi rumah?

2. Bagaimana karakteristik individu mempengaruhi pilihan lokasi rumah?

3. Bagaimana karakteristik perjalanan mempengaruhi pilihan lokasi rumah?

4. Faktor apa yang dominan mempengaruhi pengambilan keputusan pemilihan lokasi rumah?

\section{Tujuan Penelitian}

Adapun tujuan yang ingin dicapai dalam penulisan penelitian ini:

1. Mengetahui pengaruh karakteristik tempat tinggal terhadap pilihan lokasi rumah.

2. Mengetahui pengaruh karakteristik individu terhadap pilihan lokasi rumah.

3. Mengetahui pengaruh karakteristik perjalanan terhadap pilihan lokasi rumah.

4. Untuk mengetahui faktor apa yang dominan mempengaruhi pengambilan keputusan pemilihan lokasi rumah.

\section{DASAR TEORI}

\section{Konsep Tentang Perumahan dan Kawasan Permukiman}

Rumah adalah salah satu jenis ruang tempat manusia beraktivitas, harus dipandang dari seluruh sisi faktor yang mempengaruhinya dan dari sekian banyak faktor tersebut, yang menjadi pusatnya adalah manusia. Dengan kata lain, konsepsi tentang rumah harus mengacu pada tujuan utama manusia yang menghuninya dengan segala nilai dan norma yang dianutnya.

Menurut Suparno dan Marlina (2006), pengertian mengenai perumahan adalah kelompok rumah yang berfungsi sebagai lingkungan tempat tinggal atau lingkungan hunian yang dilengkapi dengan prasarana dan sarana lingkungan.

Menurut Pasal 1 angka (1) Undang-Undang Nomor 1 Tahun 2011 tentang Perumahan dan Kawasan Permukiman, yang dimaksud dengan perumahan adalah kumpulan rumah sebagai bagian dari permukiman, baik perkotaan maupun perdesaan, yang dilengkapi dengan prasarana, sarana, dan utilitas umum sebagai hasil upaya pemenuhan rumah yang layak huni.

Masyarakat manusia mulai membangun rumah setelah meninggalkan cara hidup berburu dan mengumpulkan makanan. Dalam tradisi masyarakat tradisional, rumah, lebih dari sekedar tempat bernaung dari cuaca dan segala hal yang dianggap musuh, sarat dengan makna-makna sebagai hasil pengejawantahan budaya, tradisi dan nilai-nilai yang dianut. Rumah dianggap sebagai mikro kosmos, yang merupakan bagian dari makro kosmos di luarnya serta lingkungan alam secara luas. Ini berarti bahwa manusia, konstruksi rumah, bahan bangunan serta lingkungannya seperti gunung, batu alam, pohon atau tumbuhan lainnya dapat disamakan sebagai makhluk hidup, bukan benda mati.

Menurut Pasal 1 angka (5) Undang-Undang Nomor 1 Tahun 2011 tentang Perumahan dan Kawasan Permukiman, yang dimaksud dengan permukiman adalah bagian dari lingkungan hunian yang terdiri atas lebih dari satu satuan perumahan yang mempunyai prasarana, sarana, utilitas umum, serta mempunyai penunjang kegiatan fungsi lain di kawasan perkotaan atau kawasan perdesaan.

Pasal 1 angka (3) Undang-Undang Nomor 1 Tahun 2011 tentang Perumahan dan Kawasan Permukiman, menyatakan bahwa kawasan permukiman adalah bagian dari lingkungan hidup di luar kawasan lindung, baik berupa kawasan perkotaan maupun perdesaan, yang berfungsi sebagai lingkungan tempat tinggal atau lingkungan hunian dan tempat kegiatan yang mendukung perikehidupan dan penghidupan. 
Menurut A. Turner (1972) dalam suatu permukiman, maka rumah merupakan bagian yang tidak dapat dilihat sebagai hasil fisik yang rampung semata, melainkan merupakan proses yang berkembang dan berkaitan dengan mobilitas sosial-ekonomi penghuninya dalam suatu kurun waktu.

\section{Peraturan Pembangunan Perumahan dan Kawasan Permukiman oleh Pemerintah Daerah}

Pemerintah daerah sesuai dengan amanat Undang-Undang Nomor 32 Tahun 2004, menyelenggarakan urusan pemerintahan yang menjadi kewenangannya, kecuali urusan yang menjadi urusan Pemerintah. Dalam menyelenggarakan urusan pemerintahan yang menjadi kewenangan daerah tersebut, pemerintahan daerah menjalankan otonomi seluas-luasnya untuk mengatur dan mengurus sendiri urusan pemerintahan berdasarkan asas otonomi dan tugas pembantuan.

Menurut Pasal 10 Ayat (1) dan (2) Undang-Undang Nomor 32 Tahun 2004 Tentang Pemerintahan Daerah bahwa pemerintah daerah menyelenggarakan urusan pemerintahan yang menjadi kewenangannya, kecuali urusan yang menjadi urusan pemerintah pusat. Dalam menyelenggarakan urusan pemerintahan yang menjadi kewenangannya daerah, pemerintah daerah menjalankan otonomi seluasluasnya untuk mengatur dan mengurus sendiri urusan pemerintahan berdasarkan asas otonomi dan tugas pembagian.

Pasal 14 Ayat (1) Undang-Undang Nomor 32 Tahun 2004 Tentang Pemerintahan Daerah menegaskan bahwa urusan pemerintah yang menjadi wewenang Pemerintah Kabupaten/Kota di antaranya adalah perencanaan dan pengendalian pembangunan, perencanaan, pemanfaatan, dan pengawasan tata ruang serta penyelenggaraan ketertiban umum dan ketentraman masyarakat.

\section{Pengertian Transportasi}

Transportasi adalah pemindahan manusia atau barang dari satu tempat ke tempat lainnya dalam waktu tertentu dengan menggunakan sebuah kendaraan yang digerakkan oleh manusia, hewan, maupun mesin.

Transportasi merupakan bagian yang tidak dapat dipisahkan dari kehidupan manusia. Terdapat hubungan erat antara transportasi dengan jangkauan dan lokasi kegiatan manusia, barang-barang dan jasa. Dalam kaitan dengan kehidupan manusia, transportasi memiliki peranan signifikan dalam aspek-aspek sosial, ekonomi, lingkungan, politik dan pertahanan keamanan. Dalam aspek perekonomian, transportasi mempunyai pengaruh yang besar.

Transportasi manusia atau barang biasanya bukanlah merupakan tujuan akhir, oleh karena itu permintaan akan jasa transportasi dapat disebut sebagai permintaan turunan (derived demand) yang timbul akibat adanya permintaan akan komoditas atau jasa lainnya. Dengan demikian permintaan akan transportasi baru akan ada apabila terdapat faktorfaktor pendorongnya. Permintaan jasa transportasi tidak berdiri sendiri, melainkan tersembunyi dibalik kepentingan yang lain (Morlok, 1984).

\section{METODOLOGI PENELITIAN}

\section{Flowchart}

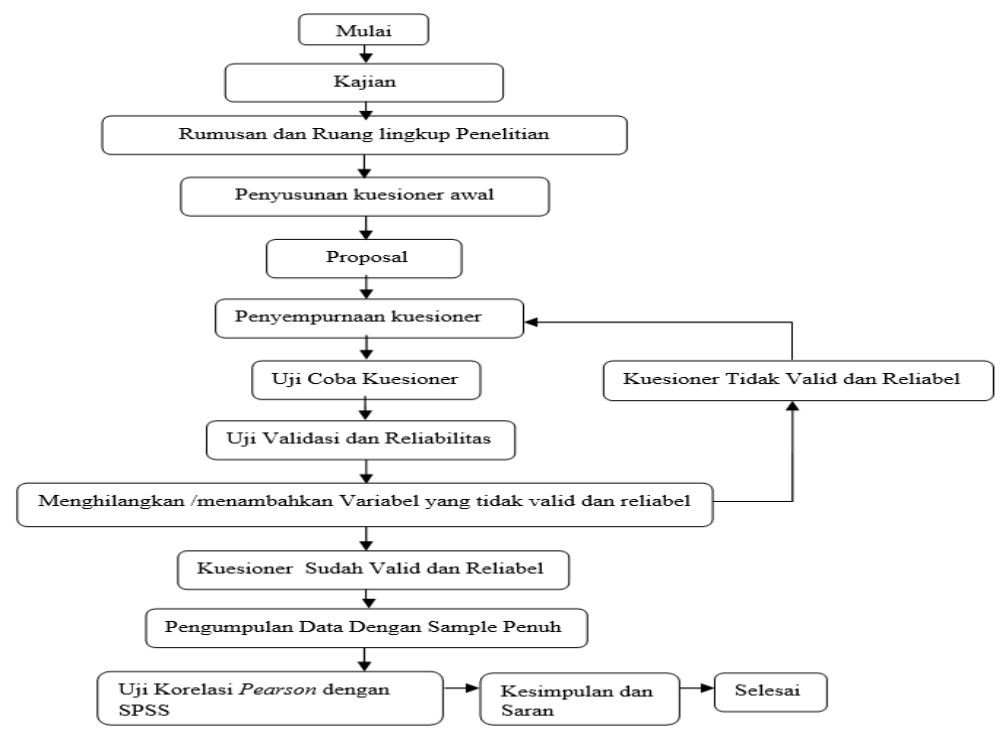

Gambar 1. Tahapan Penelitian 


\section{Prosedur Penelitian}

Dalam penelitian ini digunakan dua metode kuesioner yakni online dan langsung. Kuesioner langsung dibagikan kepada 50 responden. Responden dapat langsung bertanya kepada surveyor apabila ada butir pertanyaan yang kurang jelas. Sebanyak 52 orang mengisi melalui Google Form. Tautan untuk mengisi kuesioner tersebut dibagikan melalui email atau aplikasi seperti Whatsapp dan Line. Namun kelemahan metode kursioner online adalah responden tidak dapat langsung bertanya kepada responden.

Kuesioner berisi 2 bagian utama yakni data umum dan butir pertanyaan. Pada data umum responden diminta untuk mengisi nama, jenis kelamin, usia, agama, suku, status pernikahan, pendidikan terakhir, pekerjaan, kepemilikan kendaraan, pemakaian kendaraan sehari-hari, jenis kendaraan yang dibawa, frekuensi pemakaian kendaraan, jumlah pengeluaran keluarga, dan jumlah anggota keluarga. Pada bagian kedua dalam penelitian ini terdapat 39 butir pertanyaan yang akan diuji. Responden diminta untuk mengisi kuesioner mengenai tingkat pertimbangan, menggunakan Skala Likert dimana nilai 1 sangat tidak berpengaruh hingga nilai 4 sangat berpengaruh. Berikut adalah pertanyaan-pertanyaan yang terdapat dalam kuesioner:

1. Luas bangunan

2. Luas tanah

3. Jumlah kamar

4. Lokasi

5. Kualitas bangunan

6. Biaya pemeliharaan

7. Jaringan jalan

8. Jaringan air bersih

9. Jaringan drainase

10. Jaringan listrik

11. Jaringan telepon

12. Keamanan lingkungan

13. Kondisi fisik jalan raya

14. Kondisi fisik jalan pedesterian

15. Ketenangan suasana

16. Pendidikan

17. Kesehatan

18. Perniagaan

19. Pemerintahan

20. Pelayanan umum

21. Kebudayaan

22. Rekreasi

23. Peribadatan

24. Olah-raga (Indoor)

25. Olah-raga (Outdoor)

26. Ruang terbuka

27. Kedekatan lokasi dengan kerabat dekat

28. Kesamaan etnis

29. Kesamaan agama

30. Kemandirian

31. Biaya

32. Waktu tempuh

33. Jarak lokasi pekerjaan

34. Jarak layanan

35. Jarak ke institusi pendidikan

36. Akses jalan raya

37. Akses transportasi umum

38. Akses tata ruang berjalan

39. Akses tata ruang bersepeda

Pertanyaan nomor 1-26 masuk dalam kategori karakteristik tempat tinggal. 27-30 kategori karakteristik individu. 3139 kategori karakteristik perjalanan yang mempengaruhi keputusan pemilihan lokasi rumah. 


\section{DATA PENELITIAN}

Terdapat 102 responden yang berpartisipasi dalam penelitian ini. Tabel 1 menunjukkan distribusi data berdasarkan jenis kelamin dan usia responden.

Tabel 1. Distribusi Responden Berdasarkan Jenis Kelamin dan Usia Responden

\begin{tabular}{lrr}
\hline Jenis kelamin & Usia & Jumlah \\
\hline \multirow{4}{*}{ Pria } & 20-30 Tahun & 17 \\
& 30-40 Tahun & 21 \\
& 40-50 Tahun & 4 \\
& 50-60 Tahun & 11 \\
\multirow{4}{*}{ Wanita } & 20-30 Tahun & 26 \\
& 30-40 Tahun & 17 \\
& 40-50 Tahun & 3 \\
Total & 50-60 Tahun & 3 \\
\hline
\end{tabular}

Sebagian besar responden berusia diantara 20-30 tahun. Dari Skala Likert mengenai tiap aspek, didapati data sebagai berikut:

Tabel 2. Rangkuman Data Nilai Minimal, Nilai Maksimal dan Rataan Dari Aspek Unit Rumah

\begin{tabular}{llcccccc}
\hline No & \multicolumn{1}{c}{ Indikator } & Minimal & Maksimal & Mean & $\begin{array}{c}\text { Selisih } \\
\text { Mean }\end{array}$ & $\alpha \begin{array}{c}\text { Signifikan } \\
\text { pada } \alpha \leq 0,05 \\
\text { Ya/Tidak?) }\end{array}$ \\
\hline 1 & Luas Bangunan & 1 & 4 & 3,25 & 0,755 & $<0,001$ & Ya \\
2 & Luas Tanah & 1 & 4 & 3,25 & 0,755 & $<0,001$ & Ya \\
3 & Jumlah Kamar & 1 & 4 & 3,23 & 0,725 & $<0,001$ & Ya \\
4 & Kualitas Bangunan & 1 & 4 & 3,45 & 0,951 & $<0,001$ & Ya \\
5 & Biaya Pemeliharaan & 1 & 4 & 3,29 & 0,794 & $<0,001$ & Ya \\
\hline
\end{tabular}

Tabel 3. Rangkuman Data Nilai Minimal, Nilai Maksimal dan Rataan Dari Aspek Lingkungan

\begin{tabular}{|c|c|c|c|c|c|c|c|}
\hline No & Indikator & Minimal & Maksimal & Mean & $\begin{array}{l}\text { Selisih } \\
\text { Mean }\end{array}$ & $\alpha$ & $\begin{array}{c}\text { Signifikan pada } \\
\alpha \leq 0,05 \\
\text { (Ya/Tidak?) }\end{array}$ \\
\hline 1 & Jaringan Jalan & 1 & 4 & 3,23 & 0,725 & $<0,001$ & $\mathrm{Ya}$ \\
\hline 2 & Jaringan Air Bersih & 1 & 4 & 3,41 & 0,912 & $<0,001$ & $\mathrm{Ya}$ \\
\hline 3 & Jaringan Drainase & 1 & 4 & 3,36 & 0,863 & $<0,001$ & $\mathrm{Ya}$ \\
\hline 4 & Jaringan Listrik & 1 & 4 & 3,35 & 0,853 & $<0,001$ & $\mathrm{Ya}$ \\
\hline 5 & Jaringan Telepon & 1 & 4 & 3,02 & 0,52 & $<0,001$ & Ya \\
\hline 6 & Keamanan Lingkungan & 1 & 4 & 3,57 & 1,069 & $<0,001$ & $\mathrm{Ya}$ \\
\hline 7 & $\begin{array}{l}\text { Kondisi Fisik Jalan } \\
\text { Raya }\end{array}$ & 1 & 4 & 3,18 & 0,676 & $<0,001$ & Ya \\
\hline 8 & $\begin{array}{l}\text { Kondisi Fisik Jalan } \\
\text { Pedesterian }\end{array}$ & 1 & 4 & 2,97 & 0,471 & $<0,001$ & Ya \\
\hline 9 & Ketenangan Suasana & 1 & 4 & 3,4 & 0,902 & $<0,001$ & $\mathrm{Ya}$ \\
\hline
\end{tabular}


Pengaruh Karakteristik Perjalanan, Karakteristik Individu,

Patrick Louis, et al.

dan Karakteristik Tempat Tinggal Terhadap Keputusan

Pilihan Lokasi Rumah di Jabodetabek

Tabel 4. Rangkuman Data Nilai Minimal, Nilai Maksimal dan Rataan Dari Aspek Fasilitas

\begin{tabular}{|c|c|c|c|c|c|c|c|}
\hline No & Indikator & Minimal & Maksimal & Mean & $\begin{array}{l}\text { Selisih } \\
\text { Mean }\end{array}$ & $\alpha$ & $\begin{array}{c}\text { Signifikan } \\
\text { pada } \alpha \leq 0,05 \\
(\mathrm{Ya} / \mathrm{Tid} a k ?)\end{array}$ \\
\hline 1 & Pendidikan & 1 & 4 & 2,79 & 0,294 & 0,001 & $\mathrm{Ya}$ \\
\hline 2 & Kesehatan & 1 & 4 & 3,00 & 0,5 & $<0,001$ & $\mathrm{Ya}$ \\
\hline 3 & Perniagaan & 1 & 4 & 2,67 & 0,167 & 0,027 & $\mathrm{Ya}$ \\
\hline 4 & Pemerintahan & 1 & 4 & 2,36 & $-0,14$ & 0,079 & Tidak \\
\hline 5 & Pelayanan Umum & 1 & 4 & 2,77 & 0,275 & 0,001 & $\mathrm{Ya}$ \\
\hline 6 & Kebudayaan & 1 & 4 & 2,51 & 0,01 & 0,890 & Tidak \\
\hline 7 & Rekreasi & 1 & 4 & 2,68 & 0,176 & 0,017 & $\mathrm{Ya}$ \\
\hline 8 & Peribadatan & 1 & 4 & 2,68 & 0,176 & 0,025 & $\mathrm{Ya}$ \\
\hline 9 & Olahraga Indoor & 1 & 4 & 2,6 & 0,098 & 0,181 & Tidak \\
\hline 10 & Olahraga Outdoor & 1 & 4 & 2,62 & 0,118 & 0,120 & Tidak \\
\hline 11 & Ruang Terbuka & 1 & 4 & 2,9 & 0,402 & $<0,001$ & $\mathrm{Ya}$ \\
\hline
\end{tabular}

Tabel 5. Rangkuman Data Nilai Minimal, Nilai Maksimal dan Rataan Dari Aspek Kedekatan Lokasi Dengan Kerabat Dekat

\begin{tabular}{cccccccc}
\hline No & Indikator & Minimal & Maksimal & Mean & $\begin{array}{c}\text { Selisih } \\
\text { Mean }\end{array}$ & $\begin{array}{c}\text { Signifikan } \\
\text { pada } \alpha \leq 0,05 \\
(\text { Ya/Tidak?) }\end{array}$ \\
\hline 1 & $\begin{array}{l}\text { Kedekatan Lokasi } \\
\text { Dengan Kerabat Dekat }\end{array}$ & 1 & 4 & 2,37 & $-0,13$ & 0,070 & Tidak \\
\hline
\end{tabular}

Tabel 6. Rangkuman Data Nilai Minimal, Nilai Maksimal dan Rataan Dari Aspek Kesamaan Etnis

\begin{tabular}{cccccccc}
\hline No & Indikator & Minimal & Maksimal & Mean & $\begin{array}{c}\text { Selisih } \\
\text { Mean }\end{array}$ & $\begin{array}{c}\text { Signifikan } \\
\text { pada } \alpha \leq 0,05 \\
\text { (Ya/Tidak?) }\end{array}$ \\
\hline 1 & Kesamaan Etnis & 1 & 4 & 2,41 & $-0,09$ & 0,142 & Tidak \\
\hline
\end{tabular}

Tabel 7. Rangkuman Data Nilai Minimal, Nilai Maksimal dan Rataan Dari Aspek Kesamaan Agama

\begin{tabular}{cccccccc}
\hline No & Indikator & Minimal & Maksimal & Mean & $\begin{array}{c}\text { Selisih } \\
\text { Mean }\end{array}$ & $\begin{array}{c}\text { Signifikan } \\
\text { pada } \alpha \leq 0,05 \\
\text { (Ya/Tidak?) }\end{array}$ \\
\hline 1 & Kesamaan Agama & 1 & 4 & 2,23 & $-0,27$ & $<0,001$ & Ya \\
\hline
\end{tabular}

Tabel 8. Rangkuman Data Nilai Minimal, Nilai Maksimal dan Rataan Dari Aspek Kemandirian

\begin{tabular}{cccccccc}
\hline No & Indikator & Minimal & Maksimal & Mean & $\begin{array}{c}\text { Selisih } \\
\text { Mean }\end{array}$ & $\alpha$ & $\begin{array}{c}\text { Signifikan } \\
\text { pada } \alpha \leq 0,05 \\
\text { (Ya/Tidak?) }\end{array}$ \\
\hline 1 & Kemandirian & 1 & 4 & 2,71 & 0,206 & 0,007 & Ya \\
\hline
\end{tabular}


Tabel 9. Rangkuman Data Nilai Minimal, Nilai Maksimal dan Rataan Dari Aspek Biaya

\begin{tabular}{cccccccc}
\hline No & Indikator & Minimal & Maksimal & Mean & $\begin{array}{c}\text { Selisih } \\
\text { Mean }\end{array}$ & $\begin{array}{c}\text { Signifikan } \\
\text { pada } \alpha \leq 0,05 \\
\text { (Ya/Tidak?) }\end{array}$ \\
\hline 1 & Biaya & 1 & 4 & 3,22 & 0,716 & $<0,001$ & Ya \\
\hline
\end{tabular}

Tabel 10. Rangkuman Data Nilai Minimal, Nilai Maksimal dan Rataan Dari Aspek Waktu

\begin{tabular}{llcccccc}
\hline No & Indikator & Minimal & Maksimal & Mean & $\begin{array}{c}\text { Selisih } \\
\text { Mean }\end{array}$ & $\alpha$ & $\begin{array}{c}\text { Signifikan } \\
\text { pada } \alpha \leq 0,05 \\
\text { (Ya/Tidak?) }\end{array}$ \\
\hline 1 & Waktu & 1 & 4 & 3,33 & 0,833 & $<0,001$ & Ya \\
\hline
\end{tabular}

Tabel 11. Rangkuman Data Nilai Minimal, Nilai Maksimal dan Rataan Dari Aspek Jarak

\begin{tabular}{|c|c|c|c|c|c|c|c|}
\hline No & Indikator & Minimal & Maksimal & Mean & $\begin{array}{c}\text { Selisih } \\
\text { Mean }\end{array}$ & $\alpha$ & $\begin{array}{c}\text { Signifikan pada } \\
\alpha \leq 0,05 \\
\text { (Ya/Tidak?) } \\
\end{array}$ \\
\hline 1 & Jarak Lokasi Pekerjaan & 1 & 4 & 3,27 & 0,775 & $<0,001$ & $\mathrm{Ya}$ \\
\hline 2 & Jarak Lokasi Layanan & 1 & 4 & 3,03 & 0,529 & $<0,001$ & $\mathrm{Ya}$ \\
\hline 3 & Jarak Lokasi Sekolah & 1 & 4 & 2,86 & 0,363 & $<0,001$ & $\mathrm{Ya}$ \\
\hline
\end{tabular}

Tabel 12. Rangkuman Data Nilai Minimal, Nilai Maksimal dan Rataan Dari Aspek Aksesibilitas

\begin{tabular}{clcccccc}
\hline No & \multicolumn{1}{c}{ Indikator } & Minimal & Maksimal & Mean & $\begin{array}{c}\text { Selisih } \\
\text { Mean }\end{array}$ & $\alpha$ & $\begin{array}{c}\text { Signifikan pada } \\
\alpha \leq 0,05 \\
(\text { Ya/Tidak?) }\end{array}$ \\
\hline 1 & Akses Jalan Raya & 1 & 4 & 3,32 & 0,824 & $<0,001$ & Ya \\
2 & $\begin{array}{l}\text { Akses Transportasi } \\
\text { Umum }\end{array}$ & 1 & 4 & 3,03 & 0,529 & $<0,001$ & Ya \\
3 & $\begin{array}{l}\text { Akses Tata Ruang Ber- } \\
\text { jalan } \\
\text { Akses Tata Ruang Ber- }\end{array}$ & 1 & 4 & 2,98 & 0,48 & $<0,001$ & Ya \\
sepeda & 1 & 4 & 2,63 & 0,127 & 0,109 & Tidak \\
\hline
\end{tabular}

\section{ANALISIS DAN PEMBAHASAN}

Berdasarkan analisis dari setiap karakteristik, terdapat beberapa faktor yang mempengaruhi keputusan pemilihan lokasi rumah. Dapat dilihat bahwa pada karakteristik tempat tinggal yang sangat mempengaruhi pilihan lokasi rumah adalah faktor keamanan lingkungan dengan nilai rataan 3,57. Kualitas bangunan dengan nilai rataan 3,45. Jaringan air bersih dengan nilai rataan 3,41. Ketiga faktor ini di pengaruhi oleh latar belakang responden antara lain usia responden dan agama responden. Dimana semakin muda usia responden faktor tersebut semakin mempengaruhi keputusan pemilihan lokasi rumah. Sedangkan untuk agama cenderung responden beragama Buddha lebih mementingkan faktorfaktor tersebut. Hal ini dapat di lihat dari tabel 11 dan tabel 12. 
Pengaruh Karakteristik Perjalanan, Karakteristik Individu,

Patrick Louis, et al.

dan Karakteristik Tempat Tinggal Terhadap Keputusan

Pilihan Lokasi Rumah di Jabodetabek

Tabel 11. Korelasi Pearson terhadap Usia Responden

\begin{tabular}{lrcc}
\hline Kelompok Variabel & $\begin{array}{c}\text { Koefisien Korelasi } \\
(\mathrm{R})\end{array}$ & $\alpha$ & $\begin{array}{c}\text { Signifikan Pada } \\
\alpha \leq 0,05 \\
\text { Ya/Tidak?) }\end{array}$ \\
\hline Unit Rumah & $-0,284$ & 0,002 & Ya \\
Lingkungan & $-0,248$ & 0,006 & Ya \\
Fasilitas & $-0,275$ & 0,003 & Ya \\
Kerabat Dekat & $-0,159$ & 0,055 & Tidak \\
Kesamaan Etnis & $-0,099$ & 0,162 & Tidak \\
Kesamaan Agama & 0,076 & 0,224 & Tidak \\
Kemandirian & 0,008 & 0,466 & Tidak \\
Biaya & $-0,16$ & 0,054 & Tidak \\
Waktu & $-0,143$ & 0,76 & Tidak \\
Jarak & $-0,271$ & 0,003 & Ya \\
Aksesibilitas & $-0,262$ & 0,004 & Ya \\
\hline
\end{tabular}

Tabel 12. Korelasi Pearson terhadap Agama Responden

\begin{tabular}{lrrc}
\hline Kelompok Variabel & $\begin{array}{c}\text { Koefisien Korelasi } \\
(\mathrm{R})\end{array}$ & $\alpha$ & $\begin{array}{c}\text { Signifikan Pada } \\
\alpha \leq 0,05 \\
\text { Ya/Tidak?) }\end{array}$ \\
\hline Unit Rumah & $-0,209$ & 0,018 & Ya \\
Lingkungan & 0,017 & 0,433 & Tidak \\
Fasilitas & $-0,006$ & 0,476 & Tidak \\
Kerabat Dekat & $-0,148$ & 0,069 & Tidak \\
Kesamaan Etnis & $-0,048$ & 0,315 & Tidak \\
Kesamaan Agama & 0,035 & 0,365 & Tidak \\
Kemandirian & 0,099 & 0,16 & Tidak \\
Biaya & 0,042 & 0,337 & Tidak \\
Waktu & 0 & 0,5 & Tidak \\
Jarak & 0,082 & 0,205 & Tidak \\
Aksesibilitas & $-0,006$ & 0,476 & Tidak \\
\hline
\end{tabular}

Untuk karakteristik individu yang sangat mempengaruhi pilihan lokasi rumah adalah hanya kemandirian tinggal sendiri dengan nilai rataan 2,71. Faktor ini dipengaruhi oleh latar belakang responden yaitu suku responden. Dimana responden dengan suku Non-Chinese lebih mementingkan faktor tersebut. Hal ini dapat di lihat pada tabel 13.

Tabel 13. Korelasi Pearson terhadap Suku Responden

\begin{tabular}{|c|c|c|c|}
\hline Kelompok Variabel & $\begin{array}{l}\text { Koefisien Korelasi } \\
\text { (R) }\end{array}$ & $\alpha$ & $\begin{array}{c}\text { Signifikan Pada } \\
\alpha<0,05 \\
\text { (Ya/Tidak?) }\end{array}$ \\
\hline Unit Rumah & $-0,041$ & 0,34 & Tidak \\
\hline Lingkungan & 0,052 & 0,302 & Tidak \\
\hline Fasilitas & 0,156 & 0,059 & Tidak \\
\hline Kerabat Dekat & 0,06 & 0,274 & Tidak \\
\hline Kesamaan Etnis & $-0,083$ & 0,204 & Tidak \\
\hline Kesamaan Agama & 0,03 & 0,382 & Tidak \\
\hline Kemandirian & 0,208 & 0,018 & $\mathrm{Ya}$ \\
\hline Biaya & 0,009 & 0,463 & Tidak \\
\hline Waktu & $-0,037$ & 0,358 & Tidak \\
\hline Jarak & 0,112 & 0,131 & Tidak \\
\hline Aksesibilitas & 0,045 & 0,326 & Tidak \\
\hline
\end{tabular}

Kemudian untuk karakteristik perjalanan yang sangat mempengaruhi pilihan lokasi rumah adalah waktu tempuh dengan nilai rataan 3,33. Akses ke jalan raya dengan nilai rataan 3,32. Jarak lokasi pekerjaan dengan nilai rataan 3,27. Ketiga faktor ini dipengaruhi oleh latar belakang responden yaitu usia dan status pernikahan responden. Hal ini dapat di lihat pada tabel 13 dan tabel 14. 
Tabel 14. Korelasi Pearson terhadap Status Pernikahan Responden

\begin{tabular}{lrrc}
\hline Kelompok Variabel & $\begin{array}{c}\text { Koefisien Korelasi } \\
(\mathrm{R})\end{array}$ & $\alpha$ & $\begin{array}{c}\text { Signifikan Pada } \\
\alpha<0,05 \\
\text { Ya/Tidak?) }\end{array}$ \\
\hline Unit Rumah & $-0,171$ & 0,043 & Ya \\
Lingkungan & $-0,091$ & 0,18 & Tidak \\
Fasilitas & $-0,044$ & 0,33 & Tidak \\
Kerabat Dekat & $-0,145$ & 0,073 & Tidak \\
Kesamaan Etnis & 0,035 & 0,364 & Tidak \\
Kesamaan Agama & 0,169 & 0,045 & Ya \\
Kemandirian & 0,014 & 0,445 & Tidak \\
Biaya & $-0,22$ & 0,013 & Ya \\
Waktu & $-0,144$ & 0,075 & Tidak \\
Jarak & $-0,152$ & 0,064 & Tidak \\
Aksesibilitas & $-0,137$ & 0,085 & Tidak \\
\hline
\end{tabular}

\section{KESIMPULAN}

Berdasarkan hasil penelitian yang dilakukan, maka didapati kesimpulan:

1. Karakteristik tempat tinggal (unit rumah, lingkungan dan fasilitas) tidak sepenuhnya mempengaruhi pilihan lokasi rumah responden. Keamanan lingkungan, kualitas bangunan, dan jaringan air bersih merupakan tiga karakteristik tempat tinggal yang paling mempengaruhi pilihan lokasi rumah responden. Karakteristik tempat tinggal responden sebagian besar dipengaruhi oleh latar belakang responden antara lain usia responden dan agama responden.

2. Karakteristik individu (kedekatan dengan kerabat dekat, kesamaan suku, kesamaan agama, dan kemandirian tinggal sendiri) tidak sepenuhnya mempengaruhi pilihan lokasi rumah responden. Kemandirian tinggal sendiri merupakan yang paling mempengaruhi pilihan lokasi rumah responden Kemandirian tinggal sendiri dipengaruhi oleh suku responden.

3. Karakteristik perjalanan (biaya, waktu tempuh, jarak, dan aksesibilitas) tidak sepenuhnya mempengaruhi pilihan lokasi rumah responden. Waktu tempuh, akses ke jalan raya, dan jarak lokasi pekerjaan merupakan tiga karakteristik perjalanan yang paling mempengaruhi pilihan lokasi rumah responden. Karakteristik perjalanan responden sebagian besar dipengaruhi oleh latar belakang responden antara lain usia responden, status pernikahan responden dan penggunaan kendaraan sehari-hari.

4. Faktor yang paling dominan berpengaruh dalam pemilihan lokasi rumah responden adalah karakteristik tempat tinggal. Keamanan lingkungan sangat berpengaruh dalam karaskteristik tempat tinggal responden. Pemilihan lokasi rumah atas dasar keamanan lingkungan cenderung dilakukan oleh responden dengan usia lebih muda dibandingkan dengan usia yang lebih tua.

\section{SARAN}

Saran yang dapat diberikan untuk pemanfaatan penelitian ini :

1. Pemahaman mengenai karakteristik tempat tinggal, karakteristik individu, dan karakteristik perjalanan dapat menjadi pertimbangan untuk perencanaan lokasi hunian dan aksesibilitas moda transportasi sehingga dapat meningkatkan kesejahteraan masyarakat.

2. Sebagai bahan pertimbangan untuk pihak-pihak manapun tentang apa yang dibutuhkan masyarakat saat ini.

Saran yang dapat diberikan untuk upaya pengembangan penelitian ini lebih lanjut antara lain:

1. Penelitian selanjutnya diharapkan bisa mencari indikator lain sebagai alat pengukur dari variabel yang akan diteliti. Contoh nya indikator banjir, jenis hunian, dan lain-lain.

2. Penelitian selanjutnya diharapkan dapat memperluas populasi penelitian, yaitu dengan menambah jumlah responden. 


\section{DAFTAR PUSTAKA}

Bhat, C. R. dan Guo, J. Y. (2005). “A Comprehensive Analysis of Built Environment Characteristics on Household Residential Choice and Auto Ownership Levels". Transportation Research Part B, Vol. 41, 506-526.

Bhattacharyya. A., Jin. W., Floch. C. L., dan Chatman. D. (2018). "Nudging People Towards More Sustainable Residential Choice Decisions: An Intervention Based on Focalism And Visualization”. Springer Science Business Media, Vol. 46, 373-393.

Chatman, D. (2009). "Residential Choice, The Built Environment, And Nonwork Travel: Evidence Using New Data and Methods". Environment and Planning A 2009, Vol. 41, 1072-1089.

Huang, Q., Parker, D., dan Filatova, T. (2014). “A Review of Urban Residential Choice Models Using Agent-Based Modeling”. Environment and Planning B: Planning and Design 2014, Vol. 41, 661-689.

Huang, X., Yang, Y., dan Liu, Y. (2017). "Spatial Capital or Cultural Capital? The Residential Choice of Gentrifiers In Xuanwumen, Beijing”. Journal Housing and the Built Environment 2018, Vol. 33, 319-337.

Ibraimovic, T. dan Hess, S. (2018). "A Latent Class Model of Residential Choice Behaviour and Ethnic Segregation Preferences". Housing Studies, Vol. 33, 544-564.

Kim, Y., Campbell, H., dan Eckerd, A. (2014). "Residential Choice Constraints and Enviromental Justice". Social Science Quarterly, Vol. 95, No. 1.

Lotfi, S., Despres, C., dan Lord, S. (2018). "Are Sustainable Residential Choice Also Desirable? A Study of Household Satisfaction and Aspirations with Regards to Current and Future Residential Location”. Journal Housing and the Built Environment 2019, Vol. 34, 283-311.

Miro, F. (2005). Perencanaan Transportasi. Erlangga, Padang.

Park, J. dan Kim, K. (2016). "The Residential Location Choice of the Elderly in Korea: A Multilevel Logit Model”. Journal of Rural Studies, Vol. 44, 261-271.

Patacchini, E. dan Arduini, T. (2016). "Residential Choices of Young Americans". Journal of Housing Economics, Vol. 34, 60-81.

Republik Indonesia. (2004). Undang-Undang No. 32 Tahun 2004 tentang Pemerintah Daerah. Lembaran Negara RI Tahun 2004. Sekretariat Negara, Jakarta.

Republik Indonesia. (2007). Peraturan Pemerintah No. 41 Tahun 2007 tentang Organisasi Perangkat Daerah. Lembaran Negara RI Tahun 2007. Sekretariat Negara, Jakarta.

Republik Indonesia. (2011). Undang-Undang No. 1 Tahun 2011 tentang Perumahan dan Kawasan Permukiman. Lembaran Negara RI Tahun 2011. Sekretariat Negara, Jakarta.

Stokenberga, A. (2019). "How Family Networks Drive Residential Location Choices: Evidence from A Stated Preference Field Experiment in Bogota, Colombia". Urban Studies 2019, Vol. 56(2), 368-384.

Tu, G., Abildtrup, Jens. dan Garcia, S. (2016). "Preferences for Urban Green Spaces and Peri-Urban Forests: An Analysis of Stated Residential Choices". Landscape and Urban Planning 2016, Vol. 148, 120-131.

Yunus, S. (2005). Manajemen Kota. Pustaka Pelajar, Yogyakarta.

Yunus, S. (2012). Struktur Tata Ruang Kota. Pustaka Pelajar, Yogyakarta. 